\title{
Kesehatan hidung siswa SMA Negeri 9 Binsus Manado
}

\author{
${ }^{1}$ Carla Poli \\ ${ }^{2}$ Ora I. Palandeng \\ ${ }^{2}$ Ronaldy E. C. Tumbel
}

${ }^{1}$ Kandidat Skripsi Fakultas Kedokteran Universitas Sam Ratulangi Manado
${ }^{2}$ Bagian THT-KL Fakultas Kedokteran Universitas Sam Ratulangi Manado
Email: policarla@rocketmail.com

\begin{abstract}
Physiologically, nose has several important functions for protecting our body from the disadvantageous conditions surrounding us. This study aimed to obtain the nose health status of students at Binsus $9^{\text {th }}$ Senior High School Manado. This was a descriptive survey study with a cross sectional approach. Nose health status was determined by examination of the nasal cavity, conchae, mucous layer, secret, septum, and post nasal drip. The results showed that most of the students had normal nose health result. Conclusion: Nose health status of most students at Binsus 9 Senior High School Manado was good.
\end{abstract}

Keywords: health survey, nose examination

\begin{abstract}
Abstrak: Secara fisiologik hidung mempunyai beberapa fungsi penting sebagai penyaring, pertahanan lini pertama, dan pelindung tubuh terhadap kondisi lingkungan yang tidak menguntungkan. Penelitian ini bertujuan untuk mendapatkan gambaran kesehatan hidung pada siswa SMA Negeri 9 Binsus Manado. Desain penelitian yang digunakan ialah penelitian deskriptif survei dengan pendekatan potong lintang. Gambaran kesehatan hidung setiap sampel diperoleh dengan memeriksa kavum nasi, konka, mukosa, sekret, septum dan post nasal drip. Hasil pemeriksaan hidung menunjukkan bahwa sebagian besar gambaran kesehatan hidung siswa SMA Negeri 9 Binsus Manado normal. Simpulan: Sebagian besar siswa di SMA Negeri 9 Binsus Manado memiliki status kesehatan hidung yang baik.
\end{abstract}

Kata kunci: survei kesehatan, pemeriksaan hidung

Hidung adalah salah satu organ penting yang terlihat kecil namun vital, secara fisiologis hidung mempunyai beberapa fungsi seperti sebagai penyaring dan pertahanan lini pertama dan pelindung tubuh terhadap kondisi lingkungan yang tidak menguntungkan. ${ }^{1}$

Hidung terletak di pusat sepertiga tengah wajah dan merupakan organ tubuh paling menonjol kedepan dibandingkan dengan organ tubuh yang lain. ${ }^{2}$ Namun struktur ini sering diabaikan dalam pembicaraan penyakit manusia. ${ }^{3}$

Hidung terkadang dapat tersumbat oleh karena berbagai penyebab seperti alergi, kelainan anatomi, ataupun massa pada hidung. ${ }^{1}$ Penyakit-penyakit yang dapat timbul di hidung antara lain rhinitis alergi maupun vasomotor, deviasi septum, dan polip hidung. ${ }^{4}$

Bersin, pilek dan hidung gatal atau buntu yang sering terjadi di pagi hari merupakan salah satu gejala rhinitis alergi. Rhinitis alergi adalah salah satu penyakit 
alergi yang umumnya diderita pada usia anak sekolah dan dapat terus berlangsung sampai dewasa apabila tidak ditangani dengan baik. Angka kejadian rhinis alergi di dunia bervariasi dan dapat mencapai $40 \%$ populasi pada anak dan sekitar 10$30 \%$ pada dewasa. ${ }^{5}$

Selain itu, data dari Departemen Kesehatan Republik Indonesia (DEPKES RI) tahun 2003 menyebutkan bahwa penyakit hidung dan sinus berada pada urutan ke-25 dari 50 pola penyakit peringkat utama atau sekitar 102.817 penderita rawat jalan di rumah sakit terhitung dari anak-anak sampai dewasa. ${ }^{6}$

Anak usia sekolah merupakan generasi penerus bangsa yang akan menjadi tumpuan kualitas bangsa dalam konteks sumber daya manusia yang akan datang. Kelompok usia anak di Indonesia berjumlah sekitar 66 juta atau 28\% dari jumlah penduduk menurut hasil sensus penduduk 2010. ${ }^{5}$

Penelitian ini bertujuan untuk melakukan survei tentang kesehatan hidung pada siswa di SMA Negeri 9 Binsus Manado.

\section{METODE PENELITIAN}

Desain penelitian yang digunakan adalah penelitian deskriptif survei dengan pendekatan potong lintang. Subjek penelitian ialah siswa SMA Negeri 9 Binsus Manado yang bersedia mengikuti penelitian. Penelitian berlangsung pada tanggal 30 Oktober 2015 di SMA Negeri 9 Binsus Manado. Variabel Penelitian ialah hasil pemeriksaan hidung pada siswa SMA Negeri 9 Binsus Manado yang bersedia mengikuti penelitian dan gangguan hidung yang ditemukan pada saat pemeriksaan.

\section{HASIL PENELITIAN \\ Responden Penelitian}

Berdasarkan tabel 1 dapat dilihat bahwa jumlah responden yang mengikuti penelitian adalah 35 orang, dengan jumlah presentasi laki-laki 37,15\% dan perempuan 62,85\%. Secara keseluruhan jumlah lakilaki 13 orang sedangkan jumlah perempuan 22 orang.
Tabel 1. Jenis Kelamin Responden

\begin{tabular}{ccc}
\hline Jenis kelamin & N & $\%$ \\
\hline Perempuan & 22 & 62,85 \\
Laki-laki & 13 & 37,15 \\
Total & 35 & 100,00 \\
\hline
\end{tabular}

\section{Hasil pemeriksaan kavum nasi}

Penelitian dilaksanakan dengan melakukan pemeriksaan langsung pada siswa, dan hasil pemeriksaan diisi pada tabel pemeriksaan THT yang telah disediakan sebelumnya. Tabel pemeriksaan hidung sendiri, terdiri atas pemeriksaan kavum nasi, konka, mukosa, sekret, septum dan postnasal drip.

Tabel 2 memperlihatkan hasil pemeriksaan kavum nasi kanan dan kiri dengan hasil normal presentasinya adalah kanan 91,43\% dan kiri 91,43\%, pada pemeriksaan kavum nasi kanan dan kiri yang lapang presentasinya adalah kanan 5,72\% dan kiri 5,72\%, sedangkan hasil pemeriksaan kavum nasi kanan dan kiri yang sempit presentasinya adalah kanan 0 dan kiri 2,85\%. Jumlah secara keseluruhan dari kavum nasi kanan dan kiri yangnormal adalah kanan berjumlah 32 dan kiri 32, pada kavum nasi yang lapang yaitu kanan berjumlah 2 dan kiri 2, sedangkan kavum nasi yang sempit yaitu kanan tidak ditemukan dan kiri 1.

Tabel 2. Keadaan Kavum Nasi

\begin{tabular}{ccccc}
\hline \multirow{2}{*}{ Keadaan } & \multicolumn{2}{c}{$\mathrm{N}$} & \multicolumn{2}{c}{$\%$} \\
\cline { 2 - 5 } & Kiri & Kanan & Kiri & Kanan \\
\hline Lapang & 32 & 32 & 91,43 & 91,43 \\
Massa & 2 & 2 & 5,72 & 5,72 \\
Sempit & 1 & 1 & 2,85 & 2,85 \\
Total & 35 & 35 & 100,00 & 100,00 \\
\hline
\end{tabular}

Pemeriksaan konka kanan dan kiri pada tabel 3 memperlihatkan hasil normal kanan 82,86\% dan kiri 82,86\%, pemeriksaan konka yang udim yaitu kanan $14,29 \%$ dan kiri 14,29\%, konka yang hiperemis disertai udim yaitu kanan 2,85\% dan kiri 2,85\%, sedangakan untuk konka yang pucat, hipertrofi dan atrofi tidak ditemukan pada pemeriksaan ini. Jumlah 
secara keseluruhan dari hasil pemeriksaan pada konka kanan dan kiri adalah normal pada kanan 29 dan kiri 29, udim pada kanan 5 dan kiri 5, untuk konka yang hiperemis disertai udim pada kanan 1 dan kiri 1, sedangkan konka pucat, hipertrofi dan atrofi tidak ditemukan pada pemeriksaan.

Tabel 3. Keadaan Konka

\begin{tabular}{ccccc}
\hline \multirow{2}{*}{ Keadaan } & \multicolumn{2}{c}{$\mathrm{N}$} & \multicolumn{2}{c}{$\%$} \\
\cline { 2 - 5 } & Kiri & Kanan & Kiri & Kanan \\
\hline Normal & 29 & 29 & 82,86 & 82,86 \\
Udim & 5 & 5 & 14,29 & 14,29 \\
Udim + & 1 & 1 & 2,85 & 2,85 \\
Hiperemis & & & & \\
Pucat & 0 & 0 & 0,00 & 0,00 \\
Hipertrofi & 0 & 0 & 0,00 & 0,00 \\
Atrofi & 0 & 0 & 0,00 & 0,00 \\
Total & 35 & 35 & 100,00 & 100,00 \\
\hline
\end{tabular}

Hasil pemeriksaan mukosa kanan dan kiri pada tabel 4, dengan hasil normal presentasinya adalah kanan 82,86\% dan kiri 82,86\%. Hasil pemeriksaan hiperemia ialah kanan 5,72\% dan kiri 5,72\%, sedangkan livide presentasinya ialah kanan 11,42\% dan kiri 11,42\%. Jumlah secara keseluruhan dari hasil pemeriksaan mukosa kanan dan kiri yaitu dengan hasil normal pada kanan ialah 29 dan kiri 29, hiperemis pada kanan berjumlah 2 dan kiri 2, livide pada kanan berjumlah 4 dan kiri 4 .

Tabel 4. Keadaan Mukosa

\begin{tabular}{ccccc}
\hline \multirow{2}{*}{ Keadaan } & \multicolumn{2}{c}{$\mathrm{N}$} & \multicolumn{2}{c}{$\%$} \\
\cline { 2 - 5 } & Kiri & Kanan & Kiri & Kanan \\
\hline Normal & 29 & 29 & 88.86 & 82,86 \\
Hiperemis & 2 & 2 & 5.72 & 5.72 \\
Livide & 4 & 4 & 11,42 & 11,42 \\
Total & 18 & 18 & 100.00 & 100.00 \\
\hline
\end{tabular}

Dari hasil pemeriksaan septum kanan dan kiri pada tabel 5, dapat dilihat hasil pemeriksaan septum normal pada kanan $88,58 \%$ dan kiri $100 \%$, septum deviasi pada kanan dengan presentasi $11,42 \%$ dan kiri 0, sedangkan abses dan hematoma tidak ditemukan. Jumlah keseluruhan dari hasil pemeriksaan septum dengan keadaan normal adalah kanan 35 dan kiri 31, pada septum deviasi adalah kanan 4 dan kiri 0 , sedangkan untuk abses dan hematoma tidak ditemukan.

Tabel 5. Keadaan Sekret

\begin{tabular}{ccccc}
\hline \multirow{2}{*}{ Keadaan } & \multicolumn{2}{c}{$\mathrm{N}$} & \multicolumn{2}{c}{$\%$} \\
\cline { 2 - 5 } & Kiri & Kanan & Kiri & Kanan \\
\hline Tidak ada & 33 & 33 & 94,28 & 94,28 \\
Serous & 2 & 2 & 5,72 & 5,72 \\
Mukoid & 0 & 0 & 0,0 & 0,0 \\
Purulen & 0 & 0 & 0,0 & 0.0 \\
Total & 35 & 35 & 100.00 & 100.00 \\
\hline
\end{tabular}

Dari hasil pemeriksaan septum kanan dan kiri pada tabel 6, dapat dilihat hasil pemeriksaan septum normal pada kanan $88,58 \%$ dan kiri $100 \%$, septum deviasi pada kanan dengan presentasi $11,42 \%$ dan kiri 0, sedangkan abses dan hematoma tidak ditemukan. Jumlah keseluruhan dari hasil pemeriksaan septum dengan keadaan normal adalah kanan 35 dan kiri 31, pada septum deviasi adalah kanan 4 dan kiri 0, sedangkan untuk abses dan hematoma tidak ditemukan.

Tabel 6. Keadaan Septum

\begin{tabular}{ccccc}
\hline \multirow{2}{*}{ Keadaan } & \multicolumn{2}{c}{$\mathrm{N}$} & \multicolumn{2}{c}{$\%$} \\
\cline { 2 - 5 } & Kiri & Kanan & Kiri & Kanan \\
\hline Normal & 35 & 31 & 100,00 & 88,58 \\
Deviasi & 0 & 4 & 0,00 & 11,42 \\
Abses & 0 & 0 & 0,00 & 0,00 \\
Hematoma & 0 & 0 & 0,00 & 0,00 \\
Total & 35 & 35 & 100.00 & 100.00 \\
\hline
\end{tabular}

Berdasarkan tabel 7, tidak ditemukan adanya post nasal drip pada saat penelitian

Tabel 7. Post Nasal Drip

\begin{tabular}{ccccc}
\hline \multirow{2}{*}{ Keadaan } & \multicolumn{2}{c}{$\mathrm{N}$} & \multicolumn{2}{c}{$\%$} \\
\cline { 2 - 5 } & Kiri & Kanan & Kiri & Kanan \\
\hline Tidak Ada & 35 & 35 & 100,0 & 100,0 \\
\hline Ada & 0 & 0 & 0,0 & 0,0 \\
\hline Total & 35 & 35 & 0,0 & 0,0 \\
\hline
\end{tabular}




\section{BAHASAN}

Pada penelitian survei kesehatan hidung yang dilakukan pada siswa SMA Negeri 9 Binsus Manado dengan menggunakan pendekatan cross sectional. Penelitian ini diikuti oleh 35 orang yang bersedia menjadi responden penelitian dan responden terbanyak ialah perempuan dengan jumlah 22 orang (62,85\%) dan lakilaki dengan jumlah 13 orang (37,14\%). Pada hasil pemeriksaan yang dilakukan pada semua responden terlihat hasil normal merupakan hasil terbanyak.

Pemeriksaan kavum nasi kanan dan kiri, pada responden perempuan dengan adanya lapang pada kavum nasi adalah 1 orang, dan 21 orang sisanya normal. Pada responden laki-laki dengan adanya lapang pada kavum nasi adalah 1 orang, sempit pada kavum nasi adalah 1 orang, dan 11 orang sisanya normal.

Pada penelitian sebelumnya yang dilakukan oleh Imawo terhadap anak-anak Pasar Bersehati Komunitas Dinding Manado sebanyak 32 anak, didapatkan hasil normal pada semua sampel 32 anak $(100,00 \%)$ baik perempuan maupun lakilaki. $^{7}$

Gangguan yang dapat terjadi pada kavum nasi salah satunya adalah polip hidung. Polip hidung ialah massa lunak yang mengandung banyak cairan di dalam rongga hidung, berwarna putih keabuabuan, yang terjadi akibat inflamasi mukosa. $^{8}$

Pembentukan polip sering diasosiasikan dengan inflamasi kronik, disfungsi saraf atonom serta predisposisi genetic. Teori lain mengatakan karena ketidakseimbangan saraf vasomotor sehingga terjadi peningkatan permeabilitas kapiler dan gangguan regulasi vascular yang mengakibatkan dilepaskannya sitokinsitokin dari sel mast, yang akan menyebabkan adanya edema dan lama kelamaan menjadi polip. Bila prose terus berlanjut, mukosa yang sembab makin membesar menjadi polip dan kemudian akan turun ke rongga hidung dengan membentuk tangkai. ${ }^{8}$

Di Amerika Serikat, insiden polip nasi pada anak adalah $0,1 \%$, namun insiden ini meningkat pada anak-anak dengan fibrosis kistik yaitu $6-48 \%{ }^{9}$

Dalam penatalaksanaan polip nasi, pemberian kortikosteroid untuk menghilangkan polip nasi disebut juga polipektomi medikamentosa.Dapat diberikan topikal atau sistemik. Polip tipe eosinofilik memberikan respon yang lebih baik terhadap pengobatan kortikosteroid intranasal dibandingkan polip tipe neutrofilik. $^{8}$

Kasus polip yang tidak membaik dengan terapi medikamentosa atau polip yang sangat masif dipertimbangkan untuk terapi bedah. Dapat dilakukan ekstraksi polip menggunakan senar polip atau cunam dengan analgesik lokal, etmoidektomi intranasal atau etmoidektomi ekstranasal untuk polip etmoid, operasi Caldwell-Luc untuk sinus maksila. ${ }^{8}$

Pada pemeriksaan konka kanan dan kiri, pada responden perempuan dengan konka udim adalah 1 orang dan 21 orang sisanya normal. Pada responden laki-laki dengan konka udim adalah 4 orang, konka yang hiperemis disertai udim adalah 1 orang, dan 8 orang sisanya normal.

Pada penelitian sebelumnya yang dilakukan oleh Imawo terhadap anak-anak Pasar Bersehati Komunitas Dinding Manado sebanyak 32 anak didapatkan hasil terbanyak yaitu normal 28 anak (87,5\%) pada konka kiri dan pada konka kanan 30 anak (93,8\%). Kelainan berupa udem ditemukan pada 2 anak (6,3\%) pada konka kanan, dan hiperemis 2 anak (6,3\%) pada konka kanan dan 2 anak (6,3\%) pada konka kiri. $^{7}$

Salah satu kelaianan pada konka adalah atrofi. Atrofi konka contohnya, pada Rhinitis Atrofi. Rhinitis Atrofi merupakan infeksi hidung kronik, yang ditandai adanya atrofi progresif pada mukosa dan tulang konka dan pembentukan krusta. Secara klinis, mukosa hidung menghasilkan sekret yang kental dan cepat mengering, sehingga berbentuk krusta yang berbau busuk. Penyakit ini lebih banyak menyerang wanita daripada pria, terutama pada umur sekitar pubertas. ${ }^{10,11}$ 
Pada pemeriksaan hidung dapat ditemukan rongga hidung dipenuhi krusta hijau, kadang-kadang kuning atau hitam; jika krusta diangkat, terlihat rongga hidung sangat lapang, atrofi konka (konka nasi media dan konka nasi inferior mengalami hipotrofi atau atrofi), sekret purulen dan berwarna hijau, mukosa hidung tipis dan kering. ${ }^{9,10}$

Pemeriksaan penunjang untuk membantu menegakkan diagnosis adalah transiluminasi, foto rontgen, foto sinus paranasalis, pemeriksaan mikroorganisme, uji resistensi kuman, pemeriksaan darah tepi, pemeriksaan Fe serum, pemeriksaan histopatologi dan pemeriksaan serologi darah. $^{10}$

Pengobatan medis terbaik untuk rhinitis atrofi sampai saat ini hanya bersifat paliatif termasuk dengan irigasi dan membersihkan krusta yang terbentuk, terapi sistemik dan lokal dengan steroid dan antibiotic, vasodilator, pemakaian iritan jaringan lokal ringan seperti alcohol, dan salep pelumas. Penekanan terapi utama ialah pembedahan, yaitu usaha-usaha langsung mengecilkan rongga hidung, dan juga memperbaiki suplai darah mukosa hidung. ${ }^{11}$

Tujuan pengobatan ialah menghilangkan faktor etiologi dan menghilangkan gejala. Pengobatan dapat diberikan secara konservatif, jika tidak tertolong dilakukan operasi. ${ }^{11}$

Pada pemeriksaan mukosa kanan dan kiri, pada responden perempuan mukosa dengan hiperemis adalah 1 orang, mukosa dengan livide adalah 1 orang dan 20 orang sisanya normal. Pada responden laki-laki, mukosa dengan livide adalah 3 orang, mukosa hiperemis adalah 1 orang, dan 9 orang sisanya normal.

Pada penelitian sebelumnya yang dilakukan oleh Iwawo pada anak-anak Bersehati Komunitas Dinding Manado yang diikuti oleh 32 anak, diperoleh hasil terbanyak yaitu normal baik mukosa kanan dan mukosa kiri adalah 30 anak (93,8\%), kelainan hiperemis 2 anak (6,3\%) pada mukosa kanan dan 2 anak (6,3\%) pada mukosa kiri. ${ }^{7}$
Kelainan yang dapat terjadi pada mukosa, contohnya rinitis alergi. Rinitis alergi merupakan suatu penyakit inflamasi yang diawali dengan tahap provokasi/reaksi alergi. ${ }^{12}$

Pada pemeriksaan rinoskopi anterior mukosa hidung pada pasien alergi biasanya basah, pucat dan berwarna merah jambu keabuan disertai adanya sekret encer yang banyak. Bila gejala persisten, mukosa inferior tampak hipertrofi. ${ }^{13}$

Pada pemeriksaan sekret hidung pada responden perempuan dengan serous adalah 1 orang dan sisanya tidak ditemukan, sedangkan pada responden lakilaki dengan serous adalah 1 orang dan sisanya tidak ditemukan.

Pada penelitian sebelumnya yang dilakukan oleh Iwawo pada anak-anak Bersehati Komunitas Dinding Manado yang diikuti oleh 32 anak, diperoleh hasil terbanyak yaitu tidak ada sekret sebanyak 27 anak (84,4\%) pada hidung kanan dan 28 anak (87,5\%) pada hidung kiri. Didapatkan juga sekret serous 2 anak (6,3\%) pada hidung kanan dan 1 anak (3,1\%) pada hidung kiri, sedangkan untuk sekret mukoid yaitu 3 anak (9,4\%) baik hidung kanan maupun hidung kiri. ${ }^{7}$

Sekret serous merupakan sekret hidung yang encer yang sering ditemukan pada pasien dengan rhinitis alergi dan rinitis vasomotor. Jenis sekret ini terdiri atas protein pembuluh darah yang bocor dari pembuluh darah yang permeabel dan sering terjadi pada kasus alergi. ${ }^{14}$

Sekret purulen (nanah) merupakan sekret yang bersifat kental, putih kekuningan dan kadang berbau busuk. Sekret purulen sering ditemukan pada penderita sinusitis. Sinusitis didefinisikan sebagai inflamasi mukosa sinus paranasal, dan penyebab utamanya adalah infeksi virus yang selanjutnya dapat diikuti oleh infeksi bakteri. $^{14}$

Pada pemeriksaan septum kanan dan kiri, ditemukan 2 deviasi kanan pada lakilaki, dan 2 deviasi kanan pada perempuan, sedangkan 31 orang sisanya normal.

Pada penelitian sebelumnya yang dilakukan oleh Iwawo pada anak-anak 
Bersehati Komunitas Dinding Manado sebanyak 32 anak, diperoleh hasil terbanyak yaitu normal 31 anak (91,8\%) pada septum kanan dan 30 anak $(93,8 \%)$ pada septum kiri. Terdapat juga kelaianan deviasi 1 anak $(3,1 \%)$ pada septum kanan dan 2 anak (6,3\%) pada septum kiri. ${ }^{7}$

Salah satu kelainan pada konka adalah deviasi septum. Deviasi septum ialah suatu keadaan dimana terjadi peralihan posisi septum nasi dari letaknya yang berada di garis medial tubuh. Penyebab yang paling sering adalah trauma yang dapat terjadi sesudah lahir, pada waktu partus atau bahkan pada masa janin intrauteri. Penyebab lainnya ialah ketidak-seimbangan pertumbuhan dimana tulang rawan septum nasi terus tumbuh, meskipun batas superior dan inferior telah menetap yang kemudian terjadilah deviasi pada septum nasi itu. ${ }^{15}$

Penatalaksaan pada deviasi tergantung dari gejala yang ada. Bila keluhan sangat ringan, tidak perlu dilakukan tindakan koreksi septum sedangkan bila terdapat keluhan yang nyata dapat dilakukan tindakan operatif seperti reseksi submukosa dan reposisi septum. ${ }^{15}$

Pada pemeriksaan post nasal drip kiri dan kanan, seluruh responden baik perempuan maupun laki-laki hasilnya tidak ditemukan adanya post nasal drip.

Pada penelitian sebelumnya yang dilakukan oleh Iwawo pada anak-anak Bersehati Komunitas Dinding Manado yang diikuti oleh 32 anak tidak ditemukan kelaianan pada 32 anak (100,0\%) baik hidung kanan maupun kiri. ${ }^{7}$

Post nasal drip adalah akumulasi lendir di belakang hidung dan tenggorokan yang menjurus pada, atau memberikan sensasi dari tetesan lendir yang menurun dari belakang hidung. Ini sering terjadi pada pasien Rhinosinusitis. Rhinosinusitis adalah penyakit inflamasi mukosa yang melapisi hidung dan sinus paranasal. Peradangan ini sering bermula dari infeksi virus pada salesma, yaitu kemudian karena keadaan tertentu berkembang menjadi infeksi bakterial dengan penyebab bakteri patogen yang terdapat di saluran nafas bagian atas. ${ }^{16}$
Rinoskopi anterior merupakan pemeriksaan rutin untuk melihat tanda patognomonis, yaitu sekret purulen di meatus medius atau superior, atau pada rinoskopi posterior tampak adanya sekret purulen di nasofaring (post nasal drip). ${ }^{16}$

\section{SIMPULAN}

Berdasarkan hasil penelitian mengenai survei kesehatan hidung pada siswa di SMA Negeri 9 Binsus Manado dapat disimpulkan bahwa sebagian besar siswa di SMA Negeri 9 Binsus Manado memiliki kesehatan hidung yang baik.

\section{SARAN}

Sebaiknya untuk penderita dengan gangguan hidung yang lebih berat, perlu dilakukan pemeriksaan lebih lanjut pada bagian THT-KL dan konsultasi dokter spesialis THT, agar segera mendapatkan penanganan dan pengobatan yang lebih memadai.

\section{DAFTAR PUSTAKA}

1. Hilger PA. Hidung: Anatomi dan Fisiologi terapan. In: Adams GL, Boies LR, Higler PA. Boeis Buku Ajar Penyakit THT (6th ed). Jakarta: EGC, 1997; p. 173.

2. Snell RS. Anatomi Klinik untuk mahasiswa kedokteran (6th ed). Jakarta: EGC, 2006; p. 803.

3. Hilger PA. Hidung: Anatomi dan Fisiologi terapan. In: Adams GL, Boies LR, Higler PA. Boeis Buku Ajar Penyakit THT (6th ed). Jakarta: EGC, 1997; p. 200.

4. Soetjipto D, Mangunkusumo E, Wardani R. Sumbatan Hidung. Soepardi E, editor. Buku ajar ilmu kesehatan telinga hidung tenggorok (7th ed). Jakarta: FKUI, 2012; p. 96.

5. Depkes RI. Anak Usia Sekolah Menjadi Tumpuan Kualitas Bangsa. 2014. (diakses 20 September 2015). Tersedia dari: www.gizikia.depkes.go.id/sekretariat/ anak-usia-sekolah-menjadi-tumpuan kualitas-bangsa/

6. HTA Indonesia. Functional endoscopic sinus surgery di Indonesia (homepage on the internet). 2006. (diakses 10 
Desember 2015). Tersedia dari: http://buk.depkes.go.id/index.php

7. Iwawo R, Mengko S, Dehoop J. Survei Kesehatan Hidung Anak Pasar Bersehati Komunitas Dinding Manado. Manado: Fakultas Kedokteran Universitas Sam Ratulangi; 2015.

8. Mangunkusumo E, Wardani R. Polip Hidung. In: Soepardi E, Iskandar N, Bashirudin J, Restuti R, editors. Buku ajar ilmu kesehatan telinga hidung tenggorok (7th ed). Jakarta: FKUI, 2012; p. 101-03

9. Asnir AR. Rinitis Atrofi. 2004. (diakses 1 Desember 2015.Tersedia dari: http://www.kalbe.co.id.

10. Endang $\mathbf{M}$, Nusjirwan $\mathbf{R}$. Rinorea, Infeksi Hidung dan Sinus. Buku Ajar Ilmu Kesehatan Telinga, Hidung, Tenggorok, Kepala \& Leher (5th ed). Jakarta: Fakultas Kedokteran Universitas Indonesia, 2006.

11. Al-Faith, M. Rinitis Atrofi. 2007 (diakses 1 Desember 2015). Tersedia dari: http://hennykartika.wordpress.com

12. Irawati N, Kasakeyan E, Rusmono N.
Rinitis Alergi. In: Soepardi E, Iskanar N, Bashirudin J, Restuti R, editors. Buku Ajar Ilmu Kesehatan Telinga, Hidung, Tenggorok, Kepala \& Leher (7th ed). Jakarta. FKUI: 2012; p. 106,

13. Nguyen QA. Allergic Rhinitis. 2015. (diakses 1 Desember 2015). Tersedia dari:

http://emedicine.medscape.com/articl e/834281-overview

14. Suryadi ME. Sinusitis. 2014. (diakses 5 Desember 2015). Tersedia dari: http://repository.usu.ac.id/bitstream/1 23456789/39684/4/Chapter\%20II.pdf

15. Nizar N, Mangunkusumo E. Kelainan Septum. Soepardi E, Iskandar N, Bashirudin J, Restuti R. Buku Ajar Ilmu Kesehatan Telinga, Hidung, Tenggorok, Kepala \& Leher (7th ed). Jakarta: FKUI, 2012; p. 104-05

16. Melvin R. Pratter. Chronic Upper Airway Cough Syndrome Secondary to Rhinosinus Diseases. 2006 (diaskes 10 Desember 2015). Tersedia dari: http://chestjournal.chestpubs.org/cont ent/129/1_suppl/63S.full.html 